\title{
Comparison between three techniques for videosinuscopy in cattle
}

\author{
Comparação entre três técnicas para videosinuscopia em bovinos
}

\begin{abstract}
Fernando Zanlorenzi Basso ${ }^{\mathrm{I}}$ Eduarda Maciel Busato ${ }^{\mathrm{I}}$ Jéssica Rodrigues da Silva Rogério Luizari Guedes" Ivan Roque de Barros Filho ${ }^{\mathrm{III}}$ Peterson Triches Dornbusch ${ }^{\mathrm{II}}$
\end{abstract}

\section{ABSTRACT}

Cattle have extensive paranasal sinuses that are susceptible to disease, most commonly sinusitis. The sinuscopy can be used to evaluate these structures, although there are no descriptions of this region for endoscopic anatomy, especially regarding the trocar position and the most appropriate type of endoscope. This study aimed to standardize the surgical approaches to sinuscopy in cattle by comparing the use of three endoscopes. Four accesses by trephination (one hole for each of the maxillary and frontal sinuses) were made in eight heads of slaughtered cattle. Each hole was inspected with three endoscopes: a $10 \mathrm{~mm}$ flexible colonoscope with up to $180^{\circ}$ of angulation, a $10 \mathrm{~mm} 0^{\circ}$ laparoscope and a $4 \mathrm{~mm} 30^{\circ}$ arthroscope. It was observed that all regions of the maxillary sinus were better visualized with the $4 \mathrm{~mm}$ endoscope, and the structures of this sinus were less well visualized with the $10 \mathrm{~mm}$ laparoscope. The frontal sinus was difficult to evaluate due to the tortuosity of its bony projections, and the cranial portion was not observed by the proposed accesses. The caudal regions of the frontal sinus such as the nuchal diverticulum and the back of the orbit had the greatest number of structures visualized by the $4 \mathrm{~mm}$ endoscope, followed by the colonoscope. The comparative analysis showed that the 4mm endoscope was most efficient and could be adapted to sinuscopy in cattle.

Key words: endoscopy, videosurgery, nasal sinus, sinusitis, bovine. RESUMO

Os bovinos apresentam seios paranasais extensos e passiveis de afecções, como a sinusite. A sinuscopia, técnica já utilizada em outras espécies, avalia os seios paranasais de modo pouco invasivo e não é descrita em bovinos. O presente estudo objetivou padronizar os acessos cirúrgicos para sinuscopia em bovinos, testando três técnicas de videoendoscopia.
Foram selecionadas oito cabeças de bovinos provenientes de abatedouro comercial, sendo realizada a trepanação dos seios maxilares e frontais de ambos os lados (um orificio por seio). Cada seio foi inspecionado com três óticas: um colonoscópio flexivel com $10 \mathrm{~mm}$ de diâmetro e até $180^{\circ}$ de angulação, um laparoscópio rígido de $10 \mathrm{~mm}$ e $0^{\circ}$ e um artroscópio rígido de $4 \mathrm{~mm}$ e $30^{\circ}$. Na região caudal do seio maxilar, os alvéolos e abertura maxilopalatina foram visualizadas com todas as óticas. A região caudodorsomedial e rostral do seio maxilar foram observadas com a ótica flexível e a rígida de $4 \mathrm{~mm}$, sendo que apenas esta adentrou no seio palatino. O seio frontal é de difícil visualização, devido à tortuosidade de suas projeções ósseas e sua porção cranial não foi observada pelo acesso proposto. A região caudal do seio frontal, o divertículo nucal e a área caudal à órbita tiveram o maior número de estruturas visualizadas com a ótica rígida de $4 \mathrm{~mm}$, seguida da flexível. A análise comparativa demonstra que a técnica utilizando a ótica rígida de $4 \mathrm{~mm}$ permite a visualização de um maior número de estruturas com maior detalhamento e é a que mais se adapta à sinuscopia em bovinos.

Palavras-chave: endoscopia, videocirurgia, seios nasais, sinusite, bovino.

\section{INTRODUCTION}

The sinuses in cattle have peculiar characteristics, are underdeveloped in calves and acquire their full size after several years (DYCE et al., 2010). The frontal sinus presents rostral and caudal compartments that extend to the cornual processes. The maxillary sinuses are unique and

\footnotetext{
'Programa de Residência Multiprofissional em Saúde, Universidade Federal do Paraná (UFPR), Curitiba, PR, Brasil.

IIPrograma de Pós-graduação em Ciências Veterinárias, Universidade Federal do Paraná (UFPR), 80035-050, Curitiba, PR, Brasil. E-mail: rogerioguedes@veterinario.med.br. Corresponding author.

IIIDepartamento de Medicina Veterinária, Universidade Federal do Paraná (UFPR), Curitiba, PR, Brasil.
} Received 10.06.14 Approved 01.15.16 Returned by the author 04.08.16 CR-2014-1478.R3 
large, and enable communication with the palatine sinuses. They must be accessed via the hard palate, making the surgical approach quite difficult (SISSON \& GROSSMAN, 1998).

Among the pathologies of the sinuses, an inflammatory process called sinusitis stands out. In cattle, the leading cause of frontal sinusitis is associated with dehorning, as about $2 \%$ of surgically dehorned animals develop this disease (FIORAVANTI et al., 1999; SILVA et al., 2008). It can also be associated with respiratory infections, trepanations or fractures with frontal sinus exposure, cysts or nasal cancer (SMITH, 2006). Surgery by unqualified surgeons, the presence of foreign bodies and improper postoperative therapy are also important etiologic factors in this species (FIORAVANTI et al., 1996).

The diagnosis of sinusitis in cattle is based on history and clinical examination findings (DIRKSEN et al., 1993). In several species, in addition to a general clinical examination, some diagnostic methods can be used such as regional radiographs, sinucentesis, surgical exploration (sinusotomy), tomography and sinuscopy; the latter is performed with rigid or flexible endoscopes (ALLISON, 1999; EMSHOFF et al., 1999; SMITH, 2006).

Sinuscopy has been performed in humans (BERTRAND \& ROBILLARD, 1985; PETRUSON, 2004), horses (PERKINS et al., 2009a) and dogs (JOHNSON, 2006), due to its practicality and lower postoperative morbidity compared to conventional exploration techniques (SILVA et al., 2009). In horses, sinuscopy is widely used to properly inspect the sinuses as well to collect samples and perform biopsies on those sites. In this procedure, the animal can be kept sedated in the quadrupedal position; sinus access occurs through trepanation, which allows for the introduction of endoscopes (PERKINS et al., 2009a; O'LEARY \& DIXON, 2011). Until now, there have been no studies regarding sinuscopy in cattle, in terms of systematically describing the endoscopic anatomy of the region, the access portals and the most appropriate type of lens.

This study aimed to compare the effectiveness of three different endoscopes in sinuscopic evaluation of the maxillary, palatine and frontal sinuses of cattle in a postmortem study. The experiment also aimed to standardize the minimally invasive surgical access for sinuscopy in this species and to improve anatomical knowledge with an emphasis on the endoscopic anatomy of those regions.

\section{MATERIALS AND METHODS}

Eight cattle heads were used, obtained from commercial slaughterhouses in Curitiba and nearby cities. The heads were received skinless, dehorned and partially stripped. The access to the sinuses was carried out by a trepanning technique, first with a drill, making a small skull opening, then amplified by rotational moves with a $20 \mathrm{~mm}$ circular trephine. The chosen sites for trepanation were based on the species anatomy and facilitated by bone visualization, aiming for a bilateral evaluation of the frontal, maxillary and palatine sinuses. The access holes for the maxillary sinuses were located $3.7 \pm 0.9 \mathrm{~cm}$ rostral to the eyeball and $2.1 \pm 0.3 \mathrm{~cm}$ dorsal to the facial crest (Figure 1A). The access holes for the frontal sinuses were located $4.9 \pm 1.6 \mathrm{~cm}$ rostral to the nuchal ridge and $2.8 \pm 0.5 \mathrm{~cm}$ lateral to the midline (Figure 2A).

The equipment used for cavity inspection included a flexible colonoscope with a diameter of $10 \mathrm{~mm}$ and angles up to $180^{\circ}$ (Karl Storz, Germany), a $10 \mathrm{~mm}$ and $0^{\circ}$ laparoscope (Karl Storz, Germany), and a $4 \mathrm{~mm}$ and $30^{\circ}$ arthroscope (Karl Storz, Germany); all were coupled to a laparoscopic unit composed by a LED monitor, a microcam and a xenon light source (Telepack $^{\circledR}$, Karl Storz, Germany). The sinuses were inspected with the three endoscopes, trying to identify

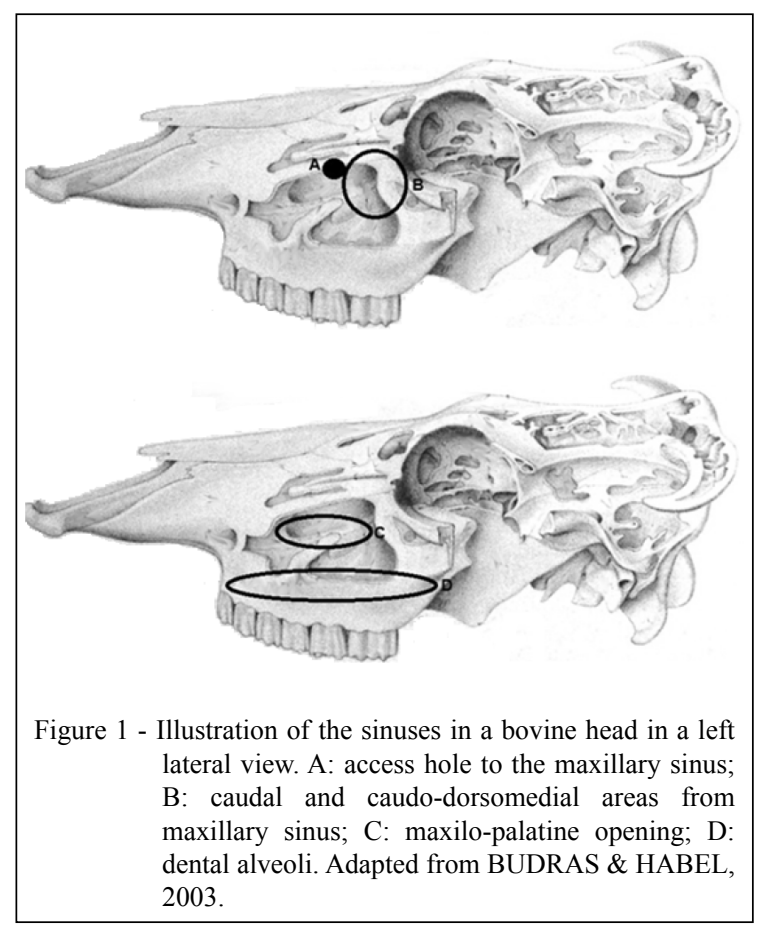




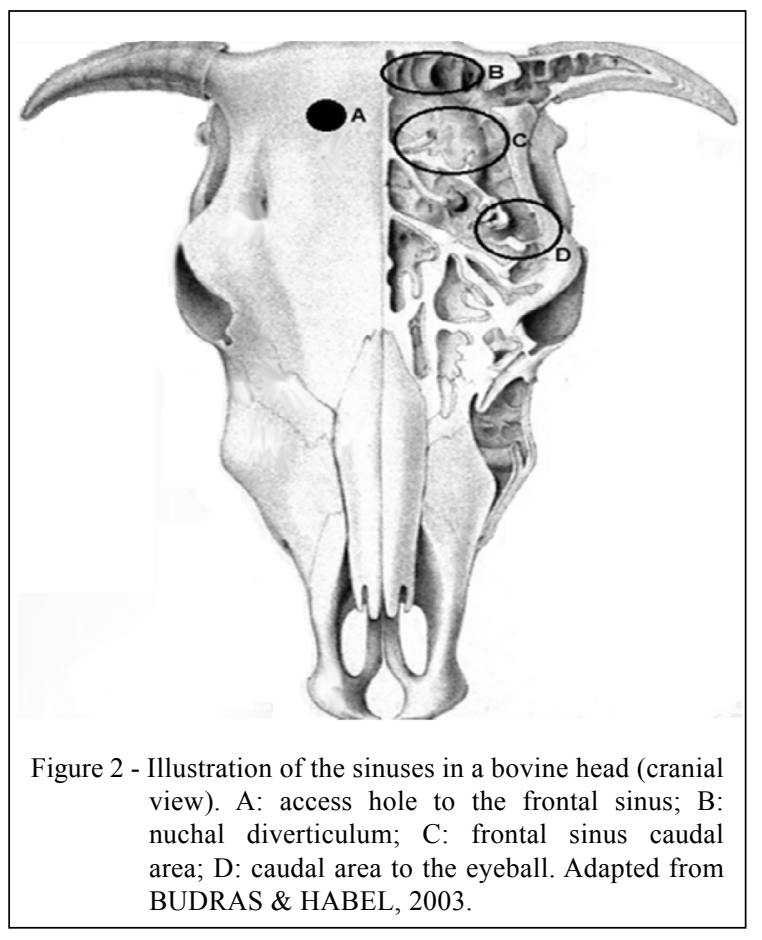

the highest number of structures possible, according to the literature and the local anatomy of this species, being classified as 1: visible or 2: not visible. All inspections were documented individually for further assessment, recording and the identified structures were tabulated. Three independant evaluators were selected, one with experience in videoendoscopic/ videolaparoscopic procedures in another species, and the other two with knowledge of cattle anatomy. The efficiency of these endoscopes was verified through their viewing capability and identification of structures by the surgeon evaluator. The group findings were statistically compared by the non-parametric KruskalWallis test, followed by Dunn's multiple comparison, using Graphpad Prism software, V5.

\section{RESULTS AND DISCUSSION}

The literature concerning cattle sinuscopy is rare, making it difficult to compare the literature with the data obtained in this study. In horses, sinuscopy is a tool used for the diagnosis, treatment and evaluation of sinusitis (PERKINS et al., 2009b; DIXON et al., 2012.). Besides horses, there are reports of sinuscopy in dogs, but it is difficult to draw interrelationships between studies of these species with cattle because they have anatomically different paranasal sinuses (PETRUSON, 2004; JOHNSON, 2006).
During this study, a 20mm diameter circular trephine was used, but smaller diameters such as 14 or $15 \mathrm{~mm}$ may be used for the same purpose (PERKINS et al., 2009b). MACHADO \& SILVA (2013) carried out an $8 \mathrm{~mm}$ trepanation to compare rigid and a flexible sinuscopy in horses, using a $4 \mathrm{~mm} 30^{\circ}$ rigid endoscope and a flexible endoscope $4.8 \mathrm{~mm}$ in diameter. Due the $10 \mathrm{~mm}$ endoscope used in the present study, it was not possible to work with smaller trephines.

The trephination areas and sinuses were selected based on anatomy, but they may be modified according to the purposes of the exam (SMITH, 2006). The main identified areas are displayed in figure 3 . Through the frontal sinus access, a caudal observation was made of this region, the nuchal diverticulum, the caudal region of the eyeball, but the exploration was complicated by the presence of large numbers of intrasinusal lamellae (Figure 3C).

Data in percentages referring to viewing capacity from different areas and techniques are compiled on table 1 . The visualization of the caudal frontal sinus area (Figure 2C) varied according to the equipment used; the $4 \mathrm{~mm} 30^{\circ}$ arthroscope was most efficient (viewing rate of $87.5 \%$ ). It was not possible to see the desired structure in only one of the eight heads, bilaterally, due the greater presence of bone irregularities therein. The colonoscope with a diameter of $10 \mathrm{~mm}$ and angles up to $180^{\circ}$ ranked second, with $62.5 \%$ successful visualizations, while the $10 \mathrm{~mm} 0^{\circ}$ endoscope had the lowest viewing rate among all tested endoscopes, as it was effective in less than half of the heads $(43.75 \%)$. Observation of the nuchal diverticulum was possible only with the arthroscope and colonoscope, in $81.25 \%$ and $12.50 \%$ of accesses, respectively (Figure 2B). During the experiment, the caudal area to the eyeball was visualized by some accesses with the arthroscope (56.25\%) and colonoscope (25\%). The laparoscope proved to be ineffective for this purpose.

The rostral region of the frontal sinus presents a tortuous anatomy, marked by intrasinusal lamellae, resulting in irregular areas (BUDRAS \& HABEL, 2003; DYCE et al., 2010), which prevent the insertion of endoscopes through the proposed access. The cornual processes were not visible because the heads were obtained from previously dehorned animals.

Inspection of the maxillary sinuses was easier and didactic when compared with the frontal sinuses, because the maxillae have a small number of tortuous bones and a more regular anatomy. This finding is in counterpoint to the purpose of the examination, since the major diseases of the bovine 


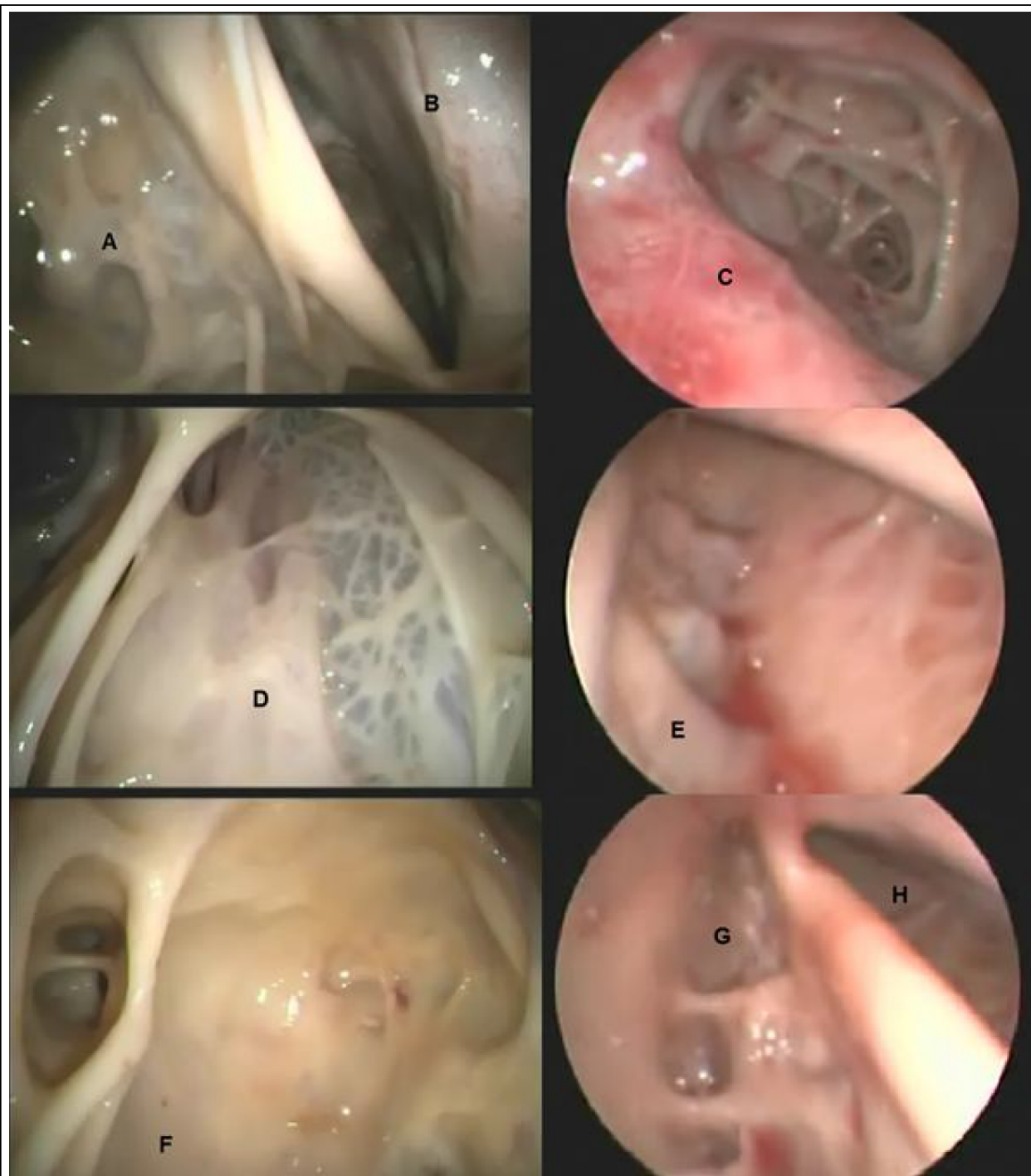

Figure 3 - Explored anatomical areas identified during the video sinuscopy in cattle. A: dental alveolus; B: maxilo-palatine opening; $\mathrm{C}$ : tortuosity from frontal sinus; D: maxillary sinus, caudo-dorsomedial portion; E: palatine sinus; F: maxillary sinus, caudal portion; G: maxillary sinus, rostral portion; H: palatine sinus.

paranasal sinuses are associated with dehorning, and therefore good visualization of the frontal sinus would be interesting (SILVA et al., 2008).

The caudal area of the maxillary sinuses achieved excellent viewing with all endoscopes used (Figure 1B; Figure 3F). The caudodorsomedial portion of the same area (Figure 1B; Figure 3D) had slightly limited inspection when the laparoscope was used, because it was ineffective in three of the 16 views. The dental alveoli (Figure 1D; Figure 3A) and the maxillopalatine opening (Figure 1C; Figure $3 \mathrm{C}$ ) were readily observed with all three endoscopes (viewing rate of $100 \%$ ); however, the palatine sinus
(Figure 3E; Figure 3H) could not be accessed in all heads. The most effective endoscopic access to the palatine sinus was achieved with the arthroscope, which attained a $93.75 \%$ viewing rate, with only one not evaluated due a narrower maxillopalatine opening than the others. The other endoscopes showed poor efficiency to this area, with a viewing rate of $25 \%$ with the colonoscope and a $6.25 \%$ with the laparoscope. The rostral region of the maxillary sinus (Figure 3G) was inspected with $100 \%$ efficiency when using the arthroscope and $87.5 \%$ efficiency with the colonoscope; however, this viewing area was not accessible with the laparoscope.

Ciência Rural, v.46, n.7, jul, 2016. 
Table 1 - View capacity (percentage and total number of animals) of the anatomical regions from paranasal sinuses in the evaluated cattle heads during the video-endoscopy techniques $(\mathrm{n}=16)$.

\begin{tabular}{|c|c|c|c|}
\hline Viewed area & Rigid optic $4 \mathrm{~mm}$ e $30^{\circ}$ & Flexible optic $10 \mathrm{~mm}$ e $180^{\circ}$ & Rigid optic $10 \mathrm{~mm}$ e $0^{\circ}$ \\
\hline Frontal sinus (rostral portion) & $0 \%(0)^{\mathrm{a}}$ & $0 \%(0)^{\mathrm{a}}$ & $0 \%(0)^{\mathrm{a}}$ \\
\hline Frontal sinus (caudal portion) & $87.5 \%(14)^{\mathrm{a}}$ & $62.5 \%(10)^{\mathrm{ab}}$ & $43.8 \%(7)^{b}$ \\
\hline Nuchal diverticulum & $81.3 \%(13)^{\mathrm{a}}$ & $12.5 \%(2)^{\mathrm{b}}$ & $0 \%(0)^{\mathrm{b}}$ \\
\hline Eyeball (caudal portion) & $56.3 \%(9)^{\mathrm{a}}$ & $25 \%(4)^{\mathrm{ab}}$ & $0 \%(0)^{\mathrm{b}}$ \\
\hline Maxilar sinus (rostral portion) & $100 \%(16)^{\mathrm{a}}$ & $87.5 \%(14)^{\mathrm{a}}$ & $0 \%(0)^{\mathrm{b}}$ \\
\hline Maxilar sinus (caudal portion) & $100 \%(16)^{\mathrm{a}}$ & $100 \%(16)^{\mathrm{a}}$ & $100 \%(16)^{\mathrm{a}}$ \\
\hline Maxilar sinus (caudo-dorsomedial portion) & $100 \%(16)^{\mathrm{a}}$ & $100 \%(16)^{\mathrm{a}}$ & $81.3 \%(13)^{\mathrm{a}}$ \\
\hline Palatine sinus & $93.8 \%(15)^{\mathrm{a}}$ & $25 \%(4)^{\mathrm{b}}$ & $6.3 \%(1)^{\mathrm{b}}$ \\
\hline Maxilo-palatine opening & $100 \%(16)^{\mathrm{a}}$ & $100 \%(16)^{\mathrm{a}}$ & $100 \%(16)^{\mathrm{a}}$ \\
\hline Dental alveoli & $100 \%(16)^{\mathrm{a}}$ & $100 \%(16)^{\mathrm{a}}$ & $100 \%(16)^{\mathrm{a}}$ \\
\hline
\end{tabular}

${ }^{\mathrm{ab}}$ Values with different superscripts in the same row are statistically different according to the Kruskal-Wallis test (P<0.05), followed by the Dunn`s multiple comparison test $(\mathrm{P}<0.05)$, using the software Graphpad Prism, V5.

\section{CONCLUSION}

A comparative analysis of the effectiveness of different endoscopes shows that a rigid endoscope with $4 \mathrm{~mm}$ and $30^{\circ}$ is the most adaptable for cattle sinuscopy, because it has a smaller diameter and a higher angulation view, which are required to access structures with a narrow opening, such as the palatine sinus. Although, more accesses sites need to be tested, trying to optimize the viewing of the other endoscopes used in this study. The maxillary and palatine sinus anatomies are more regular than the frontal sinuses, which facilitates sinuscopic inspection of the first ones. The proposed accesses to maxillary and palatine sinuses are adequate, while the techniques for frontal sinus have limitations in the rostral sinus views.

\section{BIOETHICS AND BIOSSECURITY COMMITTEE APPROVAL}

This study was submitted to the Ethics Committee for animal use of the Agricultural sciences sector (Universidade Federal do Paraná (UFPR), Brazil), following the ethical principles of the Brazilian College of Animal Experimentation (COBEA), judged and approved under the process number 101/2010.

\section{CONFLICT OF INTERESTS}

There is no conflict of interests.

\section{REFERENCES}

BUDRAS, D.K.; HABEL, E.R. Bovine Anatomy. Germany: Schlütersche, 2003. p.34-36.
DIRKSEN, G. Sistema digestivo. In: ROSENBERGER. Exame clínico dos bovinos. Rio de Janeiro RJ: Guanabara Koogan, 1993. p.166-228.

DIXON, P.M. et al. Equine paranasal sinus disease: a long-term study of 200 cases (1997-2009): treatments and long-term results of treatments. Equine Veterinary Journal, v.44, n.3, p.2725 276, 2012. Available from: <http://onlinelibrary.wiley.com/ doi/10.1111/j.2042-6 3306.2011.00427.x/abstract>. Accessed: Mar. 25, 2014. doi: 10.1111/j.2042-73306.2011.00427.x.

DYCE, K.M. et al. Cabeça e pescoço ventral do ruminante. In: Tratado de anatomia veterinária. 4.ed. Rio de Janeiro: Elsevier, 2010. p.644-663.

EMSHOFF, R. et al. Idiopathic maxillary pain: prevalence of maxillary sinus hyperreactivity in relation to allergy, chronic mucosal inflammation, and eosinophilia. Oral Surgery, Oral Medicine, Oral Pathology, Oral Radiology and Endodontology, v.87, n.6, p.685-690, 1999. Available from: <http://dx.doi. org/10.1016/S1079-2104(99)70161-7>. Accessed: Mar. 25, 2014. doi: 10.1016/S1079-2104(99)70161-7.

FIORAVANTI, M.C.S. et al. Treatment of Subcutaneous Abscesses with Methacresolsulphonic Acid Associated with Nitrofurazone and Parenteral Application of Enrofloxacin. Anais da Escola de Agronomia e Veterinária - Universidade Federal de Goiás, v.26, n.2, p.1-8, 1996.

FIORAVANTI, M.C.S. et al. Use of metal clamps for skin suture after Cattle dehorning. Ciência Rural, v.29, n.3, p.507-510, 1999. Available from: $<$ http://www.scielo.br/scielo.php?script=sci_arttext\&pid=S0103$84781999000300021 \& \operatorname{lng}=$ pt\&nrm=iso\&tlng=pt $>$. Accessed: Mar. 25, 2014. doi: 10.1590/S0103-84781999000300021.

JOHNSON, L.R. et al. Results of rhinoscopy alone or in conjunction with sinuscopy in dogs with aspergillosis: 46 cases (2001-2004). Journal of the American Veterinary Medical Association, v.228, n.5, p.738-742, 2006. Available from: <http://avmajournals. avma.org/doi/abs/10.2460/javma.228.5.738>. Accessed: Mar. 25, 2014. doi: 10.2460/javma.228.5.738. 
MACHADO, T.S.L.; SILVA, L.C.L.C. Rigid and flexible endoscope in sinoscopy and triangulation technique in equine paranasal sinus. Ciência Rural, v.43, n.12, p.2254-2260, 2013. Available from: $<$ http://www.scielo.br/scielo.php?script=sci_arttext\&pid=S010384782013001200022\&lng=pt\&nrm=iso\&tlng=en>. Accessed: Mar. 25, 2014. doi: 10.1590/S0103-7 84782013001200022.

O'LEARY, J.M.; DIXON, P.M. A review of equine paranasal sinusites. A etiopathogenesis, clinical signs and ancilliary diagnostic techniques. Equine Veterinary Education, v.23, n.3, p.148-159, 2011. Available from: $<$ http://onlinelibrary.wiley.com/ doi/10.1111/j.20423292.201110.00176.x/abstract>. Accessed: Jun. 15, 2014. doi: 10.1111/j.2042-3292.2010.00176.x.

PERKINS, J.D. et al. Comparison of sinoscopic techniques for examining the rostral maxillary and ventral conchal sinuses of horses. Veterinary Surgery, v.38, p.607-612, 2009a. Available from: <http:// onlinelibrary.wiley.com/doi/10.1111/j.1532-950X.2009.00555.x/abst ract;jsessionid=379F60710F8DC5BEA35E910997B08097.f03t02>. Accessed: Mar. 25, 2014. doi: 16 10.1111/j.1532-950X.2009.00555.x.

PERKINS, J.D. et al. Sinoscopic treatment of rostral maxillary and ventral conchal sinusitis in 60 horses. Veterinary Surgery, v.38, p. 613-619, 2009b. Available from: <http://onlinelibrary.wiley.com/ doi/10.1111/j.1532-950X.2009.00556.x/abstract;jsessionid=5966 EC4FB8464AA7D961EB29B35177B1.f03t02>. Accessed: Mar. 25, 2014. doi: 10.1111/j.1532-950X.2009.00556.x.

PETRUSON, B. Sinuscopy in patients with titanium implants in the nose and sinuses. Scandinavian Journal of Plastisc and
Reconstructive Surgery and Hand Surgery, v.38, n.2, p.86-93, 2004. Available from: <http://informahealthcare.com/doi/abs/1 0.1080/0284431031002324909>. Accessed: Mar. 25, 2014. doi: $10.1080 / 02844310310023909$.

SISSON, S.; GROSSMAN, J.D. Anatomia de los animales domesticos. 5.ed. Barcelona: Salvat, 1998. 2v.

SMITH, B.P. Doenças do Sistema Respiratório. In: Medicina interna de grandes animais. Barueri: Manole, $\overline{2006}$. p.479-592.

SILVA, L.A.F. et al. Estudo retrospectivo sobre fatores de risco e avaliação de quatro protocolos terapêuticos para sinusite em um rebanho de 2491 bovinos (1998-2008). In: CONGRESSO BRASILEIRO DE MEDICINA VETERINÁRIA, 2008, Gramado, Rio Grande do Sul. Anais... Gramado: CONBRAVET, 2008. Available from: <http://www.sovergs.com.br/conbravet2008/ anais/cd/resumos/R1028-10 3.pdf>. Accessed: Jun. 15, 2014.

SILVA, L.C.L.C. et al. Bilateral sinus cysts in a filly treated by endoscopic sinus surgery (Case report). Canadian Veterinary Journal, v.50, p.417-420, 2009.

WORSTER, A.A.; HACKETT, R.P. Equine sinus endoscopy using a flexible endoscope: diagnosis and treatment of sinus disease in the standing sedated horse. In: ANNUAL CONVENTION OF THE AMERICAN ASSOCIATION OF EQUINE PRACTITIONERS, 45., 1999, Albuquerque, New Mexico. Proceedings... Albuquerque: AAEP, 1999. p.128-130. 